\title{
Strategy making and power in environmental assessments: Lessons from the establishment of an out-of-town shopping centre in Västerås, Sweden
}

Karolina Isaksson and Sofie Storbjörk

\section{Linköping University Post Print}

N.B.: When citing this work, cite the original article.

Original Publication:

Karolina Isaksson and Sofie Storbjörk, Strategy making and power in environmental assessments: Lessons from the establishment of an out-of-town shopping centre in Västerås, Sweden, 2012, Environmental impact assessment review, (34), 65-73.

http://dx.doi.org/10.1016/j.eiar.2012.01.001

Copyright: Elsevier

http://www.elsevier.com/

Postprint available at: Linköping University Electronic Press

http://urn.kb.se/resolve?urn=urn:nbn:se:liu:diva-75047 


\section{Strategy making and power in environmental}

\section{assessments. Lessons from the establishment of an}

out-of-town shopping centre in Västerås, Sweden.

Karolina Isaksson, Mobility, actors and planning processes, Swedish National Road and

Transport Research Institute (VTI), 58195 Linköping, Sweden. Email:

karolina.isaksson@vti.se.

Sofie Storbjörk, Department of Water and Environmental Studies (DWES) and Centre for Climate Science and Policy Research (CSPR), Linköping University, 58183

Linköping, Sweden. E-mail: sofie.storbjork@liu.se

Corresponding author: Karolina Isaksson. Email: karolina.isaksson@vti.se. Phone: +46 132040 00. Fax: +4613141436. 


\section{ABSTRACT :}

This paper seeks to provide deeper insights into how EA ineffectiveness is produced in land use planning practice. This is explored in a study of local development planning in the city of Västerås, Sweden. The case in question is the development of a large out-oftown shopping centre, propelled by the establishment of a new IKEA furniture store. The Healey (2007) framework of planning as strategy making is applied as an analytical framework, together with a focus on power-knowledge relations. In the analysis, we identify a range of mechanisms that produced ineffectiveness by limiting the role of environmental knowledge throughout the planning process. The specific mechanisms we identified were related to the overall consensus perspective in local development strategies and plans, a lack of concretisation and integration of various policies and strategies, a range of exclusion mechanisms and an overall focus on mitigation and benefits of the process in question. In practice, these mechanisms were closely intertwined. Our main conclusion is, consequently, that increased effectiveness of EA would require fundamental transformation of the norms, frameworks and routines that implicitly and explicitly guide land use planning in practice.

Keywords: Environmental assessment, effectiveness, strategy making, power, environment, IKEA 


\section{Introduction}

The ambition to integrate environmental consideration has been institutionalised in various ways in local policy and planning in Sweden, just as in many other countries, and has led to the application of new frameworks, routines and practices in planning and decision making - for instance Environmental Assessments (EA). As part of the EA portfolio, Environmental Impact Assessments (EIA) have been developed to assess the environmental consequences of specific projects, and Strategic Environmental Assessments (SEA) aim to identify the environmental consequences of larger plans, programmes and policies. However, several studies have reported residual problems in transforming policy and planning in a more sustainable direction both in the Swedish context and more generally (Asplund and Skantze 2005; Edström and Eckerberg 2003; Hilding-Rydevik et al., 2011; Isaksson, 2003; Krueger and Gibbs (eds.) 2007; Lundqvist and Biel 2007; Nilsson and Eckerberg 2007; Owens and Cowell, 2002; Storbjörk et al., 2009). Several studies have explored how SEA and EIA are often used in practice to rationalise preconceived judgements or by other means strengthen prevailing norms (Hilding-Rydevik and Bjarnadóttir, 2007; Owens et al., 2004; Petts, 1999). Other writers have focused specifically on how institutional conditions, including formal and informal rules and routines, hamper the effects of EA (e.g. Nykvist and Nilsson, 2009). Several studies have focused on the clash between the rationalistic theoretical roots of EIA and the challenges involved in complex real-world situations (Owens and Cowell, 2002; Cashmore et al., 2007). Altogether, there has been an increasing emphasis on the political nature of impact assessment (Owens et al., 2004; Jay et al., 2007; Cashmore et al., 2010), and on the importance of connecting assessment procedures more closely to 'the real world institutional context that they set out to influence' (Nykvist and Nilsson, 2009). 
A considerable part of the recent literature on EA is related to the concept of effectiveness. Effectiveness is here broadly understood as a measure of goal attainment (Cashmore et al., 2010). In general, the objective with EA is often to identify expected environmental consequences of a certain enterprise in order to enable these to be taken into account, or by other means integrating environmental knowledge into planning and decision making - and thereby contributing to substantially to sustainable development (Cashmore et al., 2004, Cashmore et al., 2010). However the goal of EA may also be perceived in terms of 'capacity building', i.e. step-by-step strengthening of the capacity to take environmental consequences into account (Jay et al., 2007). Effectiveness is a complex matter because in concrete planning or policy situations, there are often different or even contradictory ambitions and understandings of the goal of an EA. Various actors may have different understandings of what it is to take environmental consequences into account and whether the goal of the EA is mainly about finding ways to mitigate impact or, in contrast, about substantially changing the policy or plan in question.

Here we view effectiveness as a performance criterion that could be related to several possible goals with EA. In the Swedish context, EA instruments have been around since the late 1980s and are generally well integrated as formal requirements in the legislative framework. Therefore, long-term capacity-building is not the key issue. We believe it to be well-justified to focus on effectiveness in terms of substantial change to policy and planning and adhere to an understanding of policy and planning situations as genuinely complex. Accordingly, as stated by Cashmore et al. (2010, p. 377), research on EA (in)effectiveness needs to relate to 'the beliefs, values and aspirations of actors engaged 
in policy decisions and impact assessment, the strategies they use to promote their visions, and the conditions under which their strategies effect change.' This brings EA research explicitly into a discussion of power, and illuminates the importance of understanding how power dynamics evolve around EA frameworks and practice (Richardson, 2005; Richardson and Cashmore, 2011).

The aim of this paper is to explore how EA ineffectiveness is produced in planning practice. We explore this in a case study of local development planning in the mediumsized city of Västerås, Sweden. The empirical case in focus is the expansion of a large out-of-town shopping centre, propelled by the establishment of a new IKEA store. In concrete terms, we explore how the EA was conducted as part of the local planning process and how it functioned as a tool for integrating environmental knowledge in the decisive elements of the process. Analytically, we apply the Healey (2007) framework of planning as strategy making, in combination with a focus on power-knowledge relations.

The paper is organised as follows. Below we first present the methodological approach used for carrying out the study, followed by a description of theoretical framework, which focuses on strategy making and power. Section 4 provides the background to land use planning and frameworks for EA in Sweden, which is followed by the analysis of the case. The paper ends with a concluding discussion.

\section{Methodological approach}

The paper is based on the results from a single case study (Stake, 1995), but was written within a wider research project involving parallel studies in two other medium-sized, expanding Swedish cities, Linköping and Örebro (Hrelja, 2011). We share the view of 
Flyvbjerg $(1998 ; 2007)$ that single case studies may serve as a sound basis for drawing more general conclusions, given that the case in question is rich and illustrative, which proved true for the case examined here. The generalisations we make are analytical, which means that we base them upon qualitative empirical material that is related to earlier research and theories from the field (Yin, 2003). The choice to base this analysis on a single in-depth case study was motivated by the fact that research questions on strategy making and power-knowledge require us to penetrate to depth and document the intricacies of planning practice and multiple perspectives of key actors involved, rather than increasing the number of case studies targeted.

Empirically, the paper builds on interviews and analysis of policy and planning documents. We held nine qualitative, semi-structured interviews with key actors in the process: six local officials, two politicians and the consultant who had worked with the EA and the EIA report (see Table 1). To identify officials to interview, we obtained help from three planners at the technical department at Västerås municipal authority, who were involved in a reference group for our research project. They helped us to identify officials from local offices who had been closely involved in the planning project. To make sure we did not miss out any key persons, however, we asked all our interviewees what other persons we should talk to if we wanted to learn more about the process. Fairly soon, we settled on a list of six officials. We also decided to interview the consultant who had prepared the EIA report as we expected that this would bring important insight on the power-knowledge aspects of planning.

When it came to politicians, our top priority was to find persons with positions in the political committees that had most insight and influence over the project and the process 
around it. Furthermore, we wanted the politicians to be particularly well acquainted with the environmental aspects of the case. This led us to two politicians from the Green Party, one of them vice-President of the Building Committee and the other a member of the Property Development Committee. The choice to interview only politicians from the Green Party meant that we did not get a representative view of how politicians in Västerås regard the project. However the interviews instead brought in experiences from two politicians who have raised questions about the project and provided more insights into how they perceived the process.

The interviews lasted between 60-90 minutes and were recorded and transcribed. The analysis was then carried out in two steps, first a meaning concentration of transcripts where specific contents in the interviews and reoccurring analytical themes were examined. Second, for this paper, we worked in more detail with themes and sections with a particular bearing on strategy making and power-knowledge relations. In the presentation and analysis of the empirical results, we have allowed singular representations - but we have generally sought to increase credence of interpretations by comparing statements from different interviews (Silverman, 1993).

In addition to the interviews, we studied general planning and policy documents like the Vision for Västerås 2026, the Comprehensive Plan, the Trade Policy, the Environmental Programme and the Strategic Plan. These documents express the stated objectives, policies and visions which constitute an important part of the policy context for the project in question. We also studied documents from the specific case studied, i.e. the local development plans for Western Erikslund, the EIA report and other documents 
that explain more of details of the case. This provided some sense of methodological triangulation.

\section{INSERT TABLE 1 HERE}

\section{Analytical framework: strategy making and power}

We found Patsy Healey's writings on planning as strategy making an interesting and innovative way to make sense of what happens (and does not happen) in a planning process. In the following analysis, we apply Healey's framework as an analytical framework for exploring the EA and planning process in this case. In her writings about planning as strategy making, Healey underlines that strategy-making 'challenges practices that are justified in terms of 'following established procedures' or 'this is what we have always done'.' (Healey, 2007 p. 30, referring to Mintzberg, 1994 and Bryson, 2003). In other words, strategy-making involves creating a dedicated process for the realisation of a certain goal or vision. This is sometimes (but not always) the case with planning activities.

Healey identifies four elements of strategy making (Healey, 2007 p. 195, referring to Mintzberg, 1994):

1) Filtering processes concerning the selection of general aims, goals, actors and perspectives defined as being important for the enterprise in question.

2 ) Focusing and framing: Many issues struggle for attention within a certain enterprise, but eventually some of them are given a privileged position. 
3) Generating mobilising force around a strategy that is recognised and positioned in a specific institutional context.

4) Creating transformative force by re-ordering categories and positions, changing existing routines and practices and establishing new ones.

Patsy Healey used the strategy-making framework to explore urban spatial strategies (Healey, 2007; 2009). Her applications have generated important insights on the performance of existing urban spatial strategic work. However we use the Healey framework slightly differently. In our study, we do not focus on the process of spatial strategy making, but on EA in land use planning. We apply the Healey framework of planning as strategy making as a way to identify and explore decisive elements in the planning process in question - i.e. elements that strongly influence subsequent steps of the process, and where a stronger consideration of environmental knowledge and concern could have significantly transformed the outcome of the planning process. We view the planning process, with the mandatory Swedish EA process as a key component, as potentially strategic in this sense. However, in the case of retail centre expansion studied here and in many other similar cases, the strategic potential was not realised.

In addition to the Healey framework, the analysis draws upon Foucault's writings about the relationship between power and knowledge. According to Foucault, knowledge just like everything else - is discursively produced and therefore also an expression of power relations. Power-knowledge relations are constantly being produced and reproduced through discursive practice which, according to Foucault, includes speech, 
text or other means of communication but also institutional arrangements and organisational structures and frameworks, including practical work, routines, common priorities, etc. (Foucault, 1976; Hajer, 1995). It is important to note that in Foucault's work there is no 'powerful subject' ruling processes and outcomes and instead power is exercised in a very decentralised manner - by all actors taking part in the discourse and thus in the (re)production of common norms, understandings and institutional conditions (Foucault, 1976).

Foucault's writings prompted us to add power-knowledge as an aspect to examine in this study. Throughout the analysis, we pay specific attention to dimensions of powerknowledge and the way they affect the role and the outcome of the EA. Special attention is paid to the way environmental knowledge was managed throughout the process; for instance the type of environmental knowledge or expertise included at various stages of the process, and the norms, routines and institutional conditions that conditioned its performance.

\section{Background: Land use planning and EA frameworks in}

\section{Sweden}

\subsection{Local planning monopoly}

Land use planning in Sweden is regulated by the Planning and Building Act (PBA) (SFS 2010:900). First introduced in 1987, it established the local planning monopoly, which means that the municipal authority 'has primary responsibility for planning the use of land and water within a legal framework set and supervised by national government' (Bjarnadóttir, 2008; SFS 1987:10). Regional or national authorities have 
no formal power over local development decisions, as long as they do not violate national regulations.

\subsection{Local planning instruments}

The two main planning instruments available to local authorities are municipal comprehensive plans (MCP) and local development plans (LDP). The MCP sets out the long-term land use and spatial development of the city. It has to balance different goals and interests in society, and make clear how national interests and environmental qualities have been considered. The MCP has an advisory function and is thus not legally binding (Bjarnadóttir, 2008; Boverket, 2006; Hilding-Rydevik and Åkerskog, 2011). The LDP, in turn, is a concrete, detailed and project-orientated planning document. It is legally binding and regulates the development of new houses, roads, industries or other facilities in a certain area or site within the municipality. In particular, a LDP specifies what may be constructed in a certain area and its exact location at the site (Bjarnadóttir, 2008; Boverket, 2006; Hilding-Rydevik and Åkerskog, 2011). In addition, there is a third form of local planning instrument: area-specific comprehensive plans (ASCP). The ASCP is more detailed than the MCP, and is legally defined as an addition to the latter. An ASCP is sometimes drawn up for the central parts of a city, or for areas in a state of intense development and where there is a need to complement the MCP with somewhat more specific guidelines.

\subsection{EA in Swedish land use planning}

EIA was introduced into the Swedish planning system in 1987, as a compulsory step in the later stages of road planning processes. Four years later, EIA was introduced into the Natural Resources Legislation (NRL) and into a suite of accompanying legislation (SFS 1991:738). After Sweden joined the EU in 1995, the Swedish EIA framework was 
further developed and adjusted in accordance with the EU Directive, manifested in the Environmental Code from 1999 (SFS 1998:808).

SEA has taken more time to become rooted in the Swedish context. The SEA Directive was formally implemented into Swedish legislation in 2005, but SEA as a concept is still not being used. Instead, the concept used in Swedish legislation since 2005 is Environmental Assessment, EA. This is somewhat confusing in relation to general EA research, since EA is an umbrella term for SEA and/or EIA processes, whereas in Swedish law EA is the formal term for the practice of SEA. In this paper, we use the term 'EA process' to refer to the Swedish practice of SEA.

The Swedish EA process may or may not include an EIA, depending on the expected environmental impact of the plan or project in question. It starts with an initial assessment (carried out by the municipal authority) of the expected environmental impact (significant or not), which in turn defines the need to conduct an EA process (SFS 2009:864). The County Administration Board and other municipalities and authorities concerned must also be consulted at this stage. The decision by the municipal authority about the need for an EA then has to be made public. If an EA is needed, the first step of the process is to define the scope of the subsequent EIA. A key element here is the consultation with the other municipalities concerned and with the County Administration Board on the scope of the EIA. It is recommended that this be done as early as possible, possibly at the same time as the consultation about the need for an EA (as mentioned above). Thereafter follows the analytical phase of data collection, analysis and processing into an EIA report, which is then released for public consultation. The EIA may lead to adjustments to the proposed plan. The final decision 
on the plan is then made. The last stage of the process is monitoring, in which the main environmental impact should be summarised and conclusions drawn. The handbooks on EA recommend that actors involved in planning and the EA process bear in mind the overall aim of the process, which is to 'integrate environmental aspects into the plan or programme so that sustainable development is promoted' (SFS 1998:808 11§). In essence, this means that the Swedish EA process, to be effective, needs to be fully integrated with the planning or programming process at hand and to follow it from the initial stages to the final and most concrete stages (SEPA 2009:7).

\section{The Western Erikslund project}

\subsection{Background}

Västerås is located in central Sweden, approximately $100 \mathrm{~km}$ from Stockholm. With 136000 inhabitants, it is the sixth largest city in Sweden. Local planning and policy documents from the early 2000s emphasise the importance of trade and shopping for the further development of central parts of the city. Out-of-town shopping is also identified as being important, and three areas have been identified as sites for the creation of outof-town shopping centres: Hälla in eastern Västerås, Stenby in the north and Western Erikslund in the west, right by the E18 motorway (Figure 1).

\section{[INSERT FIGURE 1 HERE]}

There has been an IKEA furniture store in Hälla since the early 1980s. In autumn 2006, IKEA expressed an interest in modernising and expanding the store, but it soon became clear that this would not be possible at the existing site, due to cultural heritage preservation and an overall lack of space at that location. However, the city was keen to 
meet IKEA's demands and suggested Western Erikslund as an alternative. All our interviewees from the city confirm that IKEA found the location right by the E18 motorway interesting, and describe how the planning process evolved rapidly once the city and IKEA had agreed on this alternative location. Negotiations were initiated between the Property Development Office and IKEA and soon afterwards the City Planning Office was asked to start drawing up a local development plan for the IKEA site.

IKEA's initial intention was to expand its furniture store from 16000 to 40000 square metres. However, it eventually became clear that there were larger plans for the area. Sometime along the process, Ikano Retail Centres, which is a company owned by the Kamprad family that started IKEA, entered the process and made clear that they wanted to establish a retail centre comprising around 95 retail outlets and a food outlet on an additional 40000 square metres in direct relation to the IKEA store. ${ }^{1}$ The former City Ecologist made the following comment:

'when IKEA /and Ikano/ presented their full concept of adjacent retailers /.../ the process was already well on its way. /.../ A lot of unwelcome surprises may come in a project like this. The Ikano concept has wider implications - commerce in Erikslund will increase in scope which has a bearing on sustainability.'

\footnotetext{
${ }^{1}$ There are no formal ties between the two companies IKEA and Ikano. IKEA was founded in the 1940s, by the Swedish entrepreneur Ingvar Kamprad. Since then, it has developed into a major company for furniture and home design, with shops all over the world. What the consumers know as IKEA is today only one part of a complex corporate structure consisting of several companies with activities in e.g. furniture design, furniture production and retail business. The Kamprad family is no longer the owner of IKEA, but owns the Ikano Group, which is another group of companies with main activities in finance and property development. While there are no formal links between the IKEA group and the Ikano Group, one specific company in the Ikano Group, namely Ikano Retail Centres, has as its core task to follow IKEA establishments and develop larger shopping facilities around them. It has therefore been common to think of IKEA and Ikano as interlinked, as they are often closely related in the urban landscape.
} 
The LDP for Western Erikslund, alongside an EIA report, was presented in February 2008 and approved by the City Council in May 2008. The Ikano retail centre opened in September 2011. At the same time, the former IKEA store in Hälla closed down.

The Western Erikslund project is intended to strengthen the position of Västerås as a regional centre for trading and shopping, generate new employment and increase business competitiveness and growth. In this, it is well in line with the overall development goals for the city. At the same time, however, it has led to considerable negative environmental impact. For instance, site preparation involved blasting out more than two million tonnes of rock, of which a considerable proportion had to be transported away. The project intrudes into an important recreational area which has important ecological and cultural values. Moreover, it is likely to increase transport and traffic by perhaps $35-40 \%$, thus increasing noise and air pollution locally, according to the EIA report (Grontmij, 2008). The project is also in direct conflict with the local trading policy for Västerås, which states that out-of-town shopping is only intended for durable goods and that the city should be 'very restrictive' in relation to the establishment of retail outlets, e.g. for garments and shoes, books, opticians, sports and leisure goods etc., on the outskirts of the city (Västerås, 2000).

So what can we learn from the case of Western Erikslund with respect to strategy making practices and power-knowledge relations? 


\subsection{Viewing the process through the lens of strategy making and power-knowledge}

\subsubsection{Filtering the project into the general aims and goals for the city}

As stated above, Healey (2007) identified filtering processes as a key aspect of strategymaking. Filtering is about defining general aims and goals, and identifying actors and perspectives of key importance for a certain enterprise. In the case of Western Erikslund, an immediate question arising in relation to this was how the expansion of IKEA and the Ikano retail centre was adjusted to fit into the long-term aims and goals of Västerås for sustainable urban development.

In terms of the general aims and goals for Västerås, planning and policy documents from the past decade put environmental and sustainability issues high on the agenda. 'A long-term sustainable society in harmony with nature' is the long-term goal (Västerås, 1999 p. 4), and 'quality of life' and 'a sustainable Västerås' are set out as two main targets to guide all land use decisions (Västerås, 2004). The Environmental Programme from 2005 states that Västerås will work actively and continuously to reduce its carbon footprint - through political action, business development and lifestyle changes (Västerås, 2005).

Sustainability is also given a pivotal position in policy documents for the trade and retail sectors. The local trade policy states the importance of integrating social and environmental aspects when considering new shopping facilities' (Västerås, 2000 p. 4) and, as mentioned above, it underlines that out-of-town shopping centres are only 
intended for durable goods and not for retail trade - a conscious attempt to strengthen city centre shopping (Västerås, 2000).

The policy documents convey a strong consensus view on the relationship between economic growth and environmental concerns. This is clearly manifested in the recent vision for Västerås, which is entitled 'The City with no Limits', i.e. a city where 'everything is possible' even though development should always be carried out with 'long-term sustainable solutions' (Västerås, 2010). The ambition was to establish Västerås as a regional shopping city that 'through many years of creative thinking, /has/ found a unique way to combine out-of-town shopping with a dynamic inner city.' (ibid.)

It is worthy of note that even though there are various general policy and planning documents that stress the importance of sustainable development, the relationship between various policies, strategies, programmes is never clarified in any detail. Inherent contradictions between and sometimes also within key policies are not made explicit, and no effort is made to explore whether it is at all possible to simultaneously develop Västerås as a regional centre for shopping and trading, and still live up to targets for climate concern and energy use reduction.

We see this overall consensus-orientated local urban development discourse as a central power aspect, since it sets the agenda for what is possible (and not) in terms of sustainability and frames the urban development around a very optimistic attitude to the potential to combine existing strategies for economic growth with environmental concern. It makes sense of the municipal authority's open, flexible and complaisant attitude to IKEA's ambitions to expand and the way in which the expanded IKEA and 
eventually also the Ikano retail centre was integrated so smoothly with local development work. This genuinely positive attitude clearly influenced the way the project evolved in the city administration from the very first day, and made it difficult to express any more serious questioning of the project from an environmental or sustainability perspective. Thus, it immediately had an impact on the potential role and effectiveness of the EA and meant that the EA would only be about adjusting details of the project - not challenging the concept in itself.

\subsubsection{Focusing and framing the project I: Overall priorities}

Western Erikslund was identified as an area for further expansion of external shopping in Västerås back in 2004. However, the concrete development of the site could have taken many different paths. There are always many issues that struggle for attention within a certain enterprise, so the question is which of these issues or aspects should be given a pivotal position. We opted to explore focusing and framing by analysing two things in more detail: First, the overall priorities set in the planning process (for instance in the balancing of economic and environmental aims and goals); and second, the specific details of the EA process, how it evolved and what difference it made in the case of Western Erikslund.

All interviewees expressed an awareness of the considerable environmental impact that the IKEA store and Ikano retail centre was expected to have in terms of noise, barriers, intrusion in a recreational area, increased traffic, air pollution etc. However, most of them still regarded the project as essentially positive and very important for the development of the city. The Assistant Head of the City Planning Office explained that 'the overall goal /in the process/was to keep IKEA', since it is such a 'huge magnet' for 
commerce. The project came to be strongly focused on aspects of economic prosperity and growth and on Västerås maintaining its position as a regional centre for shopping, rather than on how the development would affect the overall goals for reduced climate impact or other environmental qualities or ecological assets in the long run.

The conviction that 'we had to do this' emerged strongly in the interviews with local officials. Most of our interviewees expressed a fundamental perception of other towns and cities as competitors in a struggle for trade, growth and attractiveness, which cemented the feeling of having no choice. Overall, the expansion of out-of town shopping seemed to be regarded as a binding force that the city had to accept and comply with. The officials also reported how the IKEA store and Ikano retail centre were expected to strengthen the tax base and attract visitors and consumers within a radius of at least 100 kilometres. Figures such as these were reproduced very uncritically throughout the process, and - seeing it from the lens of power-knowledge we note how certain 'facts' strongly influenced the framing the project, and were never really challenged, even though single persons - for instance the former Head of Office for Streets and Traffic and politicians from the Green Party - expressed their doubts about the evidence base behind the numbers.

\subsubsection{Focusing and framing the project II: Filtering environmental knowledge}

Environmental knowledge was filtered in several ways throughout the process. First of all, the Property Development Office did not initiate an EA process or scope for EIA in the early stages where the agreement was settled with the retailers. The consultant who produced the EIA report for the project explained that when she started the work, she realised that the city had not yet carried out any of the overall EA process: 
'So I had to start by asking if they wanted to act in line with the legal demands or not, and yes, of course they wanted. I.../ I think they wanted to act correctly, but they were not aware of the correct procedure.'

The failure to carry out any of the prescribed EA procedures in the early stages of the planning process meant that instead of influencing the project from the very beginning, environmental knowledge production through the EA started at a stage when the LDP process had already come quite a long way. At that stage, the EA could not lead to any fundamental change to the plan. It is thus a clear illustration of institutionalised power relations that immediately led to EA ineffectiveness.

Another question is how environmental consequences - once they had been brought to light - were defined and interpreted and what role and meaning they were given. Here we note that the EIA document communicates a very pragmatic approach. In the presentation of expected consequences, emphasis is placed on compensation measures and 'making the most of it', rather than on underlining the long-term, and sometimes irreversible, environmental consequences. The fact that the Western Erikslund project is expected to increase transport and traffic by perhaps $35-40 \%$ compared with the current situation is discussed only in the detailed parts of the EIA, which states that the intended project counteracts local goals for reduced climate impact (Grontmij, 2008 p. 22). However, this is stated only briefly and not mentioned at all in the non-technical summary - which is probably the part of the document that most people and decisionmakers read. 
The non-technical summary of the EIA document focuses heavily on mitigation. The main attention is on manageable aspects such as purification of surface water and the impact on the landscape, which will be reduced by tree planting and a well-conceived site design. A lot of attention is also given to various ways to manage and/or compensate for the way the project intrudes into the habitat of the great crested newt. The mitigation efforts are encouraging in many ways, but have another side since they direct attention away from other aspects. The vice-President of the Building Committee, commented:

'Environmental considerations were made for instance in the case of the newt population. /.../ They are protected by law, so this came to affect the design of the plan to some extent. /.../ So that kind of consideration was taken. But at the same time, the issue of increased car use was brushed aside.'

The Green Party politician from the Property Development Committee made similar comments.

Another example is the focus on measures such as paths for walking and cycling and the provision of public transport, with bus stops etc. close to the entrance of the shopping facility. Most of our interviewees were positive to the efforts undertaken, but still they seemed sceptical about whether this will really make any difference in practice. With 3500 parking lots in direct connection to the centre, it will be very convenient to get to this shopping centre by car (Ikano Retail, 2010). The former Head of the Office for Streets and Traffic expressed his concerns about this by stating: 
'We make sure that the possibility of going by bicycle or bus exists but will it actually be used?'

Altogether, the focus placed on mitigation (including compensation) measures partly served to marginalise other, more complex and long-term environmental aspects such as overall traffic growth, air pollution and climate impact. It becomes clear that the knowledge production in this process intentionally or unintentionally functioned as a support for the project and not a basis for raising any more fundamental criticism. Certain environmental aspects were even framed as benefits of the project. For instance, the blasting out of more than two million tonnes of rock, which was a major intrusion in the local environment and also associated with increased noise and transport, was mentioned in the technical summary of the EIA report as an economic benefit and a matter of reduced environmental impact, in that rock would otherwise have to be bought from somewhere else and transported to the site. What was not stated was that large stocks of rock already existed in the Western Erikslund area and that only a minor part of the rock masses blasted out would actually be used on the site. The rest of the rock had to be transported away for storage and will gradually be sold and transported to other construction sites in the Mälardalen region. Whether the handling of rock in Western Erikslund will actually reduce the environmental impact is thus questionable. Framing this as a benefit for the environment gives the impression of a biased EIA report and adds to the general sense of a process where environmental knowledge was consciously filtered in order to support implementation of the IKEA expansion rather than giving a balanced account of expected environmental consequences. 


\subsubsection{Mobilising force in the City authority - Role of environmental expertise}

Looking into the institutional settings and the practical work with the plan and the EA, it is clear that the way in which the process was organised in this case - and presumably in many similar cases of land use development- led to a reproduction of existing norms and power relations. This section discusses the roles and relationships between the different committees, administrations and professions involved in the planning process for Western Erikslund and how the mobilising force - the potential to really affect the way the project was being shaped - was delegated to a specific and very limited set of actors.

The key actors from the City authority that were engaged at the very early stages of the project were the City Management Office, the Unit for Trade and Industry, leading politicians from the Property Development Committee and a limited number of officials from the Property Development Office. Together, they constituted a core network that worked intensively with the project at a very early informal, and in many ways decisive, stage of the process. Meetings were held under strict rules of secrecy. There was no representation of environmental expertise and the initiative and power to influence remained among a limited number of actors with their main interest and competences in economic growth and business development. Furthermore, even though the EA process is supposed to be initiated at the very beginning of any local development planning process, this did not happen in this case. This is a clear restriction on the ability of the EA process to make any real difference beyond compensatory measures or other more limited adjustments. 
The way the work was organised in this case also led to problems for the consultant responsible for producing the EIA document. All through the process, she had severe problems in obtaining basic information about the project being planned. She was not allowed to participate at project meetings and she was never informed that it was an IKEA store and retail centre that was being planned:

'The municipality did not give us all information because it was still secret that it was about a new IKEA-store - it was still in a stage of discussion, perhaps at a political level /.../. So at maps and other documents we got /.../ we could see that it was a huge building and we did ask what kind of enterprise it would be, because we wanted to know how much traffic to expect for instance, which is crucial for the EIA. What kind of enterprise would it be? But we did not get any clear information to begin with, so what we knew at that time was that it could be about shopping and/or small industry establishments. /.../ After a while, however, we were informed that it would be a large shopping facility'.

Even though it was eventually made clear that it was a new large shopping facility that was being planned for, there was no information that it was an IKEA store and Ikano retail centre, which is indeed a very specific facility. From the interview with the EIA consultant, we learn that the County Administration Board, the public authority responsible for reviewing plans and EIA reports, was also not fully informed of what the project was about when it was consulted about the project and the need for an EA. This affected the way in which the EIA could constitute a platform for deliberation, which is a clearly stated intention according to Swedish and EU frameworks (Isaksson et al., 2009). The fact that the EIA report - or any other documents from the EA process 
- did not include any precise information on the project also meant that it was difficult to scrutinise the expected outcomes of the project as they were presented in the planning documents and the EIA report. So, instead of opening up for dialogue around the project, the main function of the EIA in this case was to stabilise the plan, in a way that is very similar to what has been identified in earlier research (Jay et al., 2007; Petts, 1999). What we see is a strong institutionalisation of power-relations that marginalises any more critically orientated persons, professions and knowledge from having any major impact on the process. As a consequence, it was difficult to generate any mobilising force for environmental knowledge and expertise. The EA and EIA could not influence the process in the way intended in the planning and environmental legislation.

\section{Concluding discussion}

The Western Erikslund project illustrates a number of general problems concerning the role of EA in local development planning. However, the main contribution of this study does not lie in showing the existence of EIA ineffectiveness, as that has been done very convincingly before, but rather in the insights it provides on how EA ineffectiveness is being produced in local land use planning practice. It illuminates how a range of mechanisms together help to limit the role of the EA and environmental knowledge throughout the whole planning process. To conclude the paper, we now list and discuss the most significant of these mechanisms. 


\subsection{Key mechanisms for ineffectiveness}

\subsubsection{An overall consensus perspective paving the way}

First, we have noted how the overall visions and plans for the city of Västerås established a consensus perspective on the potential to combine environmental concern and economic growth. This perspective represents a very common approach to sustainable development today, and it has earlier been discussed for instance in terms of ecological modernisation and post-political framing of sustainability (Hilding-Rydevik et al., 2011; Swyngedouw, 2007). But even though it is common, it still represents a very specific perspective on what environmental consideration is (and is not) about; it restricts any more 'radical' or 'challenging' approach, and in this case it clearly paved the way for how the IKEA and Ikano establishments could be merged into the long-term strategies and development plans of Västerås.

\subsubsection{Lack of concretisation of parallel policies}

In relation to this, we have also noted an overall lack of concretisation of the overall policies, plans and strategies - and a lack of clarification of how they are related to each other. In practice, local policy, planning and decision-making rests on a range of separate policy ambitions (the Trade Policy, the Environmental Programme, the Strategic Plan, etc.), where goal conflicts remains unexplored and hidden under an overall consensus umbrella. This, in turn, helps to reproduce the consensus perspective and keep it unchallenged and enables the implementation of projects that in essence contradict some of the stated policy aims. Our finding here is closely related to what Hrelja (2011) discusses in his study of the expansion of out-of-town shopping in the city of Örebro, Sweden, where a central conclusion is that many of the concrete routines in 
policy and planning practice help to avoid having to consider long-term policy goals in individual planning projects. Our findings here are yet another expression of this mechanism.

The analysis also highlights some of the more practical and hands-on elements of the EA and planning process and shows the various ways in which environmental knowledge was restricted from substantially influencing the Western Erikslund project.

\subsubsection{Lack of integration + exclusion mechanisms}

The case of Western Erikslund illustrates an EA and land use planning process where environmental knowledge had an important, but in several ways very limited, position throughout the process. As has been pointed out in earlier research (see, for instance, Retief et al., 2007), there was a clear lack of integration of the EA with the planning and decision making process. This is partly related to the issue of timing; as pointed out by Bjarnadóttir (2008), among others, the EA process often starts too late - in this case after the key decisions had been taken. Thus, instead of being a determinant in whether to proceed with the project or what restrictions to impose by providing a balanced account of expected environmental consequences, which is intended by the legislation, the EA process was initiated when it could no longer make any substantial change to the plan.

A closely related aspect is the exclusion of environmental expertise. At the early and in many ways decisive stage of the planning process, there was no environmental knowledge or expertise involved at all. When environmental experts were involved later on in the process, their role was circumscribed by other means - for instance in the case 
of the EIA consultant by not having access to all the relevant information on what the project was about.

\subsubsection{Implicit norms, assumptions and figures shaping the process}

It also became clear, throughout our interviews, that the local policy making was very much framed by an implicit - and very powerful - perception of the new IKEA store in Western Erikslund as being of key importance for the city's long-term development. The overall concern was about maintaining the position of Västerås as a regional centre for shopping and commerce. A general impression from the interviews is that it would have been very difficult to try to challenge this overall attitude, which characterised much of the decision making and planning process. In relation to power and knowledge it is however worthy of note that the positive claims made for Western Erikslund in terms of its input to local growth and development rested upon a number of assumptions that were uncritically reproduced to support the project, without any clearly stated evidence. The officials we interviewed mentioned various factors, such as people's attitude to IKEA centres, the number of visitors a new retail centre will attract, the catchment distances, the number of new jobs it will lead to and how this will strengthen the position of Västerås in relation to neighbouring towns and cities. Some of the assumptions are not unlikely, but some of them are, and altogether they rest on a very diffuse evidence base that was not pronounced clearly in any of the public documents. It is interesting to note how perceptions such as these acquired such a powerful role in the framing of the project. 


\subsubsection{A focus on mitigation + framing expected environmental impact as beneficial}

Earlier studies have noted that EIA often involves a strong focus on mitigation instead of offering any substantial critique of the policy or plan in question (Cashmore et al., 2007; Jay et al., 2007;Kornov et al., 2005). This was also reflected in the present case, where we noted that the long-term impact on traffic and climate change was not mentioned at all in the non-technical summary of the EIA report and the main focus was put on mitigation efforts such as public transport investments, paths for walking and cycling and efforts to move the newt population. We have also identified how certain irreversible environmental consequences - e.g. the blasting out of more than two millions of tonnes of rock - were inexplicably reframed as environmental benefits in the EIA report. Altogether, we see this as yet another illustration of the power-knowledge relation, which in this case came to mean that potentially challenging environmental knowledge or information was kept in a marginal position and thus could not garner any strength to transform the process and its outcome. Instead, the environmental aspects highlighted in the EIA report helped to adjust the plan in a way that supported the implementation of the project.

\subsection{Concluding reflections}

Our findings in this case echo much of the existing knowledge about ineffective EA in planning practice. Environmental considerations were made in several ways throughout the process, but only to the extent that they did not challenge anything fundamental in the plan for Western Erikslund, with the new IKEA store and the Ikano retail centre as key establishments. The illustration of ineffective EA is in itself not new, but has been a 
recurring theme in EA literature over the last 10-15 years. The main contribution of this study is instead the identification of decisive elements in the EA and planning process, where the key mechanisms listed above together served to disarm the EA of its transformative potential, and led to a situation where it could not substantially change the outcome of the planning process. The Healey framework of strategy making enabled us to see how these mechanisms were closely intertwined throughout the planning process.

In general, we found the Healey framework to be a very useful approach for understanding what happened (and not) in the EA and land use planning process. A general lesson from the study is that EA ineffectiveness is being produced and reproduced dynamically through several elements and mechanisms, which are closely intertwined. The production of EA ineffectiveness is deeply embedded in the norms, routines and practices and power relations that structure local land use planning in practice. In essence, this means that all attempts to increase EA effectiveness (so that it may have a more substantial impact on planning and decision making), would also require transformation of the fundamental norms and power-relations that steer planning practice. Here too we see the potential of the Healey framework: just as it can be used to identify key elements of how ineffectiveness is produced, it can also be used to identify key measures for realising the strategic potential of EA land use planning practice. Accomplishing this in an EA context is an important theme for future research. 


\section{Acknowledgements:}

The study was funded by The Swedish Governmental Agency for Innovation Systems (VINNOVA), grant number 2008-03203. We want to thank our project colleagues and all the members of the reference group for the project for their helpful contributions. Special thanks go to our interviewees, who took their time to meet and discuss this case with us. Also, thanks to Mary McAfee for her excellent work with language editing of the paper.

\section{References}

Asplund E, andSkantze A, editors. Hållbar utveckling i praktiken. Möten, gränser, perspektiv [Sustainable development in practice. Encounters, borders and perspectives] Stockholm: TRITA-INFRA 05-011.

Bjarnadóttir H. SEA in the context of land-use planning: the application of the EU directive 2001/42/EC to Sweden, Iceland and England. Karlskrona: Blekinge Institute of Technology, Licentiate Dissertation Series 1650-2140, 2008:11; 2008.

Boverket. Miljöbedömningar för planer enligt plan- och bygglagen - en vägledning. [Environmental assessments for plans according to the planning and building legislation - a guide] Karlskrona: Boverket; 2006. 
Cashmore M, Bond A, Cobb D. The Contribution of Environmental Assessment to Sustainable Development: Toward a Richer Empirical Understanding. Environmental Management 2007; 40:516-530.

Cashmore M, Qwilliam R, Morgan R, Cobb D, Bond A. The interminable issue of effectiveness: substantive purposes, outcomes and research challenges in the advancement of environmental impact assessment theory. Impact Assessment Project Appraisal 2004; 22: 295-310.

Cashmore M, Richardson T, Hilding-Rydevik T, Emmelin L. Evaluating the effectiveness of impact assessment instruments: Theorising the nature and implications of their political constitution. Environmental Impact Assessment Review 2010; 30: 371379.

Edström, C and Eckerberg K. Svenska kommuners arbete med Agenda 21 - en jämförelse över tid. [Swedish municipalities’ work with Agenda 21 - comparisons over time]. Stockholm: Temo Tryck AB; 2002.

Flyvbjerg, B. Rationality and Power: Democracy in Practice. Translated by Steven Sampson. Chicago: University of Chicago Press; 1998.

Flyvbjerg, B. Five Misunderstandings about Case-Study Research. In: Seale C, Gobo G, Jaber F, Silverman D, editors. Qualitative Research Practice: Concise Paperback Edition. London and Thousand Oaks, CA: Sage, 2007, pp. 390-404. 
Foucault, M. The history of sexuality volume 1. London: Penguin Books; 1976.

Grontmij. Detaljplan för Västra delen av Erikslund I Västerås.

Miljökonsekvensbeskrivning. Utställningshandling 20080206. [Develepment plan for Western Erikslund I Västerås. Environmental Impact Assessment. 20080206] Västerås stad: Fastighetskontoret; 2008.

Hajer, M A. The Politics of Environmental Discourse. Ecological Modernisation and the Policy Process. Oxford: Oxford University Press; 1995.

Healey, P. Urban complexity and spatial strategies: towards a relational planning for our times. London: Routledge; 2007.

Healey, P. In Search of the "Strategic" in Spatial Strategy Making. Planning Theory \& Practice, 10: 4, 439 - 457.

Hilding-Rydevik T, Bjarnadóttir H. Context awareness and sensitivity in SEA implementation. Environmental Impact Assessment Review 2007; 27: 666-684.

Hilding-Rydevik T, Åkerskog A. A clear case of 'doublespeak': the Swedish governmental SEA implementation discourse'. Journal of Environmental Planning and Management, 54: 4, 495 - 515. 
Hilding-Rydevik T, Håkansson M. Isaksson K. "Sustainable growth” - the Swedish governmental discourse on sustainable regional development. International Planning Studies, 16: 2, 169-187.

Hrelja, R: The Tyranny of Small Decisions. Unsustainable Cities and Local Day-to-Day Transport Planning. Planning Theory \& Practice 2011; 12:4 511-524.

Ikano Retail. Erikslund Västerås. Nytt köpcentrum med IKEA under samma tak [Erikslund Västerås. A new retail centre with IKEA under the same roof]. Ikano Retail Centres; 2010.

Isaksson K. Hållbarhet. Avvägningar, prioriteringar, utmaningar. Planerares erfarenheter av de tre hållbarhetsdimensionerna. [Sustainability: Balancing, priorities, challenges. Planners' experiences of the three dimensions of sustainability] Stockholm: TRITA-INFRA 04-003; 2003.

Isaksson K, Richardson T, Olsson K. Tracing deliberative norms in Environmental Impact Assessment Frameworks: The case of Swedish roads planning. Environmental Impact Assessment Review 2009; 29:295-304.

Jay S, Jones C, Slinn P, Wood C. Environmental impact assessment: Retrospect and prospect. Environmental Impact Assessment Review 2007; 27: 287-300.

Kornov L, Christensen P, Nielsen EH. Mission impossible: does environmental impact 
assessment in Denmark secure a holistic approach to the environment? Impact Assessment and Project Appraisal 2005; 23:4 303-314.

Krueger R, Gibbs D, editprs. The Sustainable Development Paradox. Urban Political Economy in the United States and Europe. New York: The Guilford Press; 2007.

Lundqvist LJ, Biel A. From Kyoto to the Town Hall. Making International and National Climate Policy Work at the Local Level. London: Earthscan; 2007.

Nilsson M, Eckerberg K. Environmental Policy Integration in Practice. Shaping Institutions for Learning. London: Earthscan; 2007.

Nykvist B, Nilsson M. Are impact assessment procedures actually promoting sustainable development? Institutional perspectives on barriers and opportunities found in the Swedish committee system. Environmental Impact Assessment Review 2009; 29: $15-24$.

Owens S, Cowell R. Land and limits: interpreting sustainability in the planning process. London: Routledge; 2002.

Owens S, Rayner T, Bina O. New agendas for appraisal: reflections on theory, practice, and research. Environment and Planning A 2004; 36:1943-1959.

Petts J. Handbook on Environmental Assessment. London: Blackwell Science; 1999. 
Retief F, Jones C, Jay S. The emperor's new clothes - Reflections on strategic environmental assessment (SEA) practice in South Africa. Environmental Impact Assessment Review 2008; 28:504-514.

Richardson T. Environmental assessment and planning theory:

four short stories about power, multiple rationality, and ethics. Environmental Impact Assessment Review 2005; 25: 341-365.

Richardson T, Cashmore M. Power, knowledge and environmental assessment: the World Bank's pursuit of 'good governance'. Journal of Political Power 2011; 4:1 105125.

SEPA (Swedish Environmental Protection Agency). Handbok med allmänna råd om miljöbedömning av planer och program. Handbok 2009:1. [Handbook for environmental assessment of plans and programs]. Stockholm: Naturvårdsverket; 2009.

SFS. Förordning om miljökonsekvensbeskrivningar; 1991:738

SFS. 1987:10-12, Plan- och bygglag. Lag om exploateringssamverkan. Lag om hushållning med naturresurser m.m.. (1987). Stockholm: Fakta Info Direkt AB

SFS 1998:808 Miljöbalk. Stockholm: regeringen. 
SFS 2009:864 Förordning (1998:905) om miljökonsekvensbeskrivningar. Stockholm: miljödepartementet.

SFS 2010:900 Plan- och bygglag. Stockholm: socialdepartementet.

Silverman D. Interpreting Qualitative Data. London: Sage Publications, 1993.

Storbjörk S, Lähteenmäki-Smith K, Hilding-Rydevik T. Conflict or consensus: The challenge of integrating environmental sustainability into regional development programming. European Journal of Spatial Development 2009; 34:1-22.

Stake RE. The Art of Case-Study Research. London: Sage Publications; 1995.

Swyngedouw E. Impossible "sustainability" and the postpolitical condition. In: Krueger R, Gibbs D, editors. The Sustainable Development Paradox. Urban Political Economy in the United States and Europe. New York: The Guilford Press; 2007.

Västerås 1999: Översiktsplan. City of Västerås.

Västerås 2000: Handelspolicy. City of Västerås.

Västerås 2004: ÖP för Västerås tätort. City of Västerås.

Västerås 2005: Environmental programme for Västerås. City of Västerås. 
Västerås 2007: Strategic plan. City of Västerås.

Västerås 2010: Målbild 2026. City of Västerås.

Yin RK. Case study research: design and methods. 3 ed. Thousand Oaks: Sage Publications; 2003. 